\title{
2013 International Conference on Environmental Specimen Banks: Securing a Strategy to Monitor Emerging Pollutants in the Regional and Global Environment
}

\author{
Jianfu Zhao • Paul R. Becker • Xiang-Zhou Meng
}

Received: 25 September 2014 / Accepted: 9 October 2014 / Published online: 25 October 2014

(C) Springer-Verlag Berlin Heidelberg 2014

Environmental Specimen Bank (ESB) has been recognized for several decades as an important complement to environmental monitoring and research programs, with the following two possible reasons: (1) to evaluate the results of governmental environmental policies and regulations and (2) to conduct the monitoring and research either in ecological or human health (Becker et al. 2006). Currently, 28 ESBs (three in USA, three in France, two in Canada, two in Denmark, two in Spain, two in UK, two in Italy, two in Japan, two in Korea, one in Sweden, one in Germany, one in Norway, one in Finland, one in Portugal, one in South Africa, one in China, and one in Australia) have been established worldwide, and the values of ESB are becoming more broadly recognized by the scientific and management community (Day et al. 2014).

The international workshop/conference has had a great influence on the development and direction of ESBs over the last three decades (Becker et al. 2006). As shown in Table 1, more than 20 international ESB meetings (including special ESB sessions in conference) have been held in different cities since the first International Workshop on the Use of Biological Specimens for the Assessment of Human Exposure to Environmental Pollutants in Luxembourg in April 1977. Clearly, most of these gatherings happened in the developed

Responsible editor: Philippe Garrigues

J. Zhao $\cdot$ X.-Z. Meng $(\bowtie)$

State Key Laboratory of Pollution Control and Resources Reuse,

College of Environmental Science and Engineering, Tongji

University, 1239 Siping Road, Shanghai 200092, China

e-mail: xzmeng@tongji.edu.cn

J. Zhao

e-mail: zhaojianfu@tongji.edu.cn

\section{P. R. Becker}

National Institute of Standards and Technology, Hollings Marine Laboratory, 331 Fort Johnson Road, Charleston, SC 29412, USA e-mail: paul.becker@nist.gov countries, such as the USA, Germany, and Japan. In October 2013, the International Conference on Environmental Specimen Banks was the first ESB symposium held in Shanghai, China, which probably is the first time for the developing countries. The reason is that Chinese environmental problems as well as their related ecosystem stress and human health risk have raised wide concerns along with the rapid economic development in recent years. Environmental pollution caused by legacy pollutants such as heavy metals, nitrogen, phosphorus, organochlorine pesticides (OCPs), and polycyclic aromatic hydrocarbons (PAHs) are still a big problem in China that need to be resolved. Meanwhile, emerging contaminants (ECs) including polybrominated diphenyl ethers (PBDEs), perfluorinated compounds (PFCs), and pharmaceutical and personal care products (PPCPs) were detected with elevated concentrations in specific regions of China. Thus, the monitoring and research on the integrated chemical contaminants and subsequent ecosystem health are the big challenges to the future development of ESB, especially for the counties at the early stage of ESB.

The 2013 International Conference on Environmental Specimen Banks in Shanghai was the latest in a series of international ESB conferences (Table 1), with the objective to provide a focus discussion on the sustainable development, management, and international cooperation of Environmental Specimen Bank network coping with regional and global environmental changes. An International Scientific Committee including 11 members from the USA, Sweden, Japan, Germany, Australia, and China was organized under the chairmanship of Jianfu Zhao from Tongji University, China and Paul R. Becker from Hollings Marine Laboratory, USA. The topics of the conference include several aspects as follows, but not be limited to.

- Monitoring emerging pollutants in the regional and global environment

- Development and applications of ESB 
Table 1 Environmental Specimen Bank (ESB) workshops and conferences worldwide (information from Becker et al. 2006, Iwnao 1998, and the database of International Environmental Specimen Bank Group)

\begin{tabular}{|c|c|c|}
\hline Time & Location & Title \\
\hline April 1977 & Luxembourg & $\begin{array}{l}\text { International Workshop on the Use of Biological Specimens } \\
\text { for the Assessment of Human Exposure to Environmental } \\
\text { Pollutants }\end{array}$ \\
\hline $\begin{array}{c}\text { October } \\
1978\end{array}$ & Berlin, Germany & $\begin{array}{l}\text { International Workshop on Monitoring Environmental } \\
\text { Materials and Specimen Banking }\end{array}$ \\
\hline May 1982 & $\begin{array}{l}\text { Saarbrucken, } \\
\text { Germany }\end{array}$ & $\begin{array}{l}\text { International Symposium on Environmental Specimen } \\
\text { Banking and Monitoring as Related to Banking }\end{array}$ \\
\hline May 1988 & Beyreuth, Germany & $\begin{array}{l}\text { 11th US-German Seminar of State and Planning on } \\
\text { Environmental Specimen Banking }\end{array}$ \\
\hline $\begin{array}{l}\text { September } \\
1989\end{array}$ & Ottawa, Canada & $\begin{array}{l}\text { Canadian Specimen Banking Seminar and 12th US-German } \\
\text { Seminar of State and Planning on Environmental Specimen } \\
\text { Banking }\end{array}$ \\
\hline $\begin{array}{l}\text { September } \\
1991\end{array}$ & Vienna, Austria & $\begin{array}{l}\text { International Symposium on Biological and Environmental } \\
\text { Specimen Banking }\end{array}$ \\
\hline $\begin{array}{l}\text { December } \\
1995\end{array}$ & Honolulu, Hawaii & Environmental Biomonitoring and Specimen Banking Symposium \\
\hline May 1996 & Stockholm, Sweden & $\begin{array}{l}\text { Second International Symposium \& Workshop on Biological } \\
\text { Environmental Specimen Banking }\end{array}$ \\
\hline $\begin{array}{l}\text { November } \\
1997\end{array}$ & Osaka, Japan & $\begin{array}{l}\text { International Workshop on Ultra-Long-Term Cryogenic } \\
\text { Preservation Network of Biological and Environmental Specimens }\end{array}$ \\
\hline $\begin{array}{l}\text { March } \\
2000\end{array}$ & Tokyo, Japan & $\begin{array}{l}\text { Second International Workshop on Ultra-Long-Term } \\
\text { Cryogenic Preservation Network of Biological and Environmental } \\
\text { Specimens }\end{array}$ \\
\hline $\begin{array}{l}\text { March } \\
2004\end{array}$ & Matsuyama, Japan & $\begin{array}{l}\text { A special symposium session on "Specimen Bank and retrospective } \\
\text { trends" in the 1st International Symposium on } \\
\text { Environmental Behavior } \\
\text { and Ecological Impacts of Persistent Toxic Substance }\end{array}$ \\
\hline $\begin{array}{l}\text { March } \\
2004\end{array}$ & Tsukuba, Japan & $\begin{array}{l}\text { International Workshop on Time Capsule for Environment and } \\
\text { Endangered Wildlifes }\end{array}$ \\
\hline $\begin{array}{l}\text { November } \\
2005\end{array}$ & $\begin{array}{l}\text { Charleston, South } \\
\text { Carolina, USA }\end{array}$ & International Environmental Specimen Bank (IESB) Symposium \\
\hline $\begin{array}{l}\text { September } \\
2007\end{array}$ & Tokyo, Japan & $\begin{array}{l}\text { A ESB session in the DIOXIN 2007: 27th International Symposium } \\
\text { on Halogenated and Persistent Organic Pollutants }\end{array}$ \\
\hline $\begin{array}{r}\text { August } \\
2008\end{array}$ & Sydney, Australia & $\begin{array}{l}\text { A session on "the role of Environmental Specimen Banks in } \\
\text { retrospective } \\
\text { assessment" in the 5th SETAC World Congress }\end{array}$ \\
\hline June 2009 & Göteborg, Sweden & $\begin{array}{l}\text { A session on "frozen history - Environmental Specimen Banks" } \\
\text { in the 19th Annual Meeting SETAC Europe }\end{array}$ \\
\hline $\begin{array}{l}\text { December } \\
2009\end{array}$ & Matsuyama, Japan & International Symposium on Environmental Specimen Bank \\
\hline June 2010 & Berlin, Germany & Conference for European Environmental Specimen Banks \\
\hline $\begin{array}{c}\text { November } \\
2010\end{array}$ & Berlin, Germany & International Conference for Environmental Specimen Banks \\
\hline $\begin{array}{l}\text { November } \\
2011\end{array}$ & Marseille, France & $\begin{array}{l}\text { A session on "are Environmental Specimen Banks ready to face } \\
\text { future challenges of environmental chemistry and regulatory } \\
\text { toxicology?" in } \\
\text { the ESBB Inaugural Conference }\end{array}$ \\
\hline May 2012 & Berlin, Germany & $\begin{array}{l}\text { A session on "challenges and opportunities for Museum \& } \\
\text { Environmental } \\
\text { Biobanks" in the 6th SETAC World Congress } 2012 \text { / SETAC } \\
\text { Europe 22nd Annual Meeting }\end{array}$ \\
\hline $\begin{array}{c}\text { October } \\
2013\end{array}$ & Shanghai, China & International Conference on Environmental Specimen Banks \\
\hline
\end{tabular}

1. Design of ESB including information system

2. Collection, preparation, and conservation of ESB samples
3. Analysis, measurement, and standardization of ESB samples 
4. Sustainable development and management of ESB

5. Creation of data portals to link specimens to data generated on specimens

- Environmental and health research based on environmental specimen

- Cooperative scientific research based on international ESB network

The 2013 International ESB Conference in Shanghai prepared a representative forum for lectures (4 plenary, 27 oral, and 40 poster presentations) and inspiring discussions, which attracted over 100 scientists and representatives of environmental agencies from more than 10 countries. It is apparent from the discussions and presentations at the 2013 International ESB Conference that future directions of the ESBs will involve more cooperation to deal with regional and global environmental issues, especially ECs of concern. Next international ESB conference will be held in Nice, France in Spring 2015 and hosted by the Perennial Observatory of the Environment (OPE), with a focus on the mechanisms for enhancing international cooperation in environmental specimen banking.

This Environmental Science and Pollution Research (ESPR) Special Issue entitled "Developments and Applications of Environmental Specimen Banks for Monitoring Emerging Contaminants" features a collection of scientific papers presented by experts at the 2013 International ESB Conference and invited scientists who are experts in the field of ESB or ECs. Overall, 31 papers address the latest development of ESB and the scientific advancements in the distribution, toxicity, risk, and removal of ECs in the environment. For example, the historical development of ESB in China and the environmental specimen banking at the National Institute for Environmental Studies in Japan over the past three decades were summarized for the first time. Andra ESB established in 2010 in France was introduced by Leclerc and coworkers, as a part of the OPE, ongoing Long-Term Environmental Research Monitoring and Testing System. Venkatesan and coworkers also presented the creation and related studies of National Sewage Sludge Repository (NSSR) at the Biodesign Institute, as part of the Human Health Observatory $(\mathrm{H} 2 \mathrm{O})$ at Arizona State University. In addition, two interesting studies have been conducted based on German ESB, including the use of monitoring data in EU chemicals management and biometric parameters of the (Abramis brama) as indicators to observe long-term changes in fish health and environmental quality. Furthermore, more work should be done on international cooperation, new technology for sample management, and consideration the combination of chemical and biological endpoints for the future perspectives of ESB.

ECs were detected in various environmental compartments and raised wide concerns. Bao and coworkers reviewed the literature data on five typical groups of ECs, i.e., chlorinated paraffins (CPs), dechlorane plus and related compounds (DPs), hexabromocyclododecanes (HBCDs), phthalate esters, and pyrethroids, accumulated between 2003 and 2013 to clarify the global trends of research on ECs in the environment and humans. The distributions of several ECs were investigated in the coast of California, USA, the Bohai and Yellow seas, the Bosten Lake, the Pearl River and Suzhou Creek, the Chaohu Lake, the East China Sea, even lakes in public parks of Shanghai, China. The toxicity, human exposure, and human health risk of several ECs were also examined in the papers from this Special Issue. In addition, the behavior and fate of ECs during wastewater treatment were addressed in order to further develop removal technology. Without considering potential increases in the production, use, and release of new chemicals, several thousands of ECs will be released to the toxicosphere between today and 2050. Present ESBs should be used more broadly for the assessment of potential ECs, as highlighted by Ionan Marigómez, Jan Koschorreck, and Olivier Donard in a session on "challenges and opportunities for Museum \& Environmental Biobanks" in the 6th SETAC World Congress 2012 / SETAC Europe 22nd Annual Meeting.

We sincerely thank all of the sponsors of the 2013 International ESB Conference including the State Key Laboratory of Pollution Control and Resource Reuse and the Key Laboratory of Yangtze River Water Environment (Ministry of Education), China, and International Group of Environmental Specimen Banks. We very much acknowledge the support and help by the ESPR Editor-in-Chief Dr. Philippe Garrigues and by the Editorial Assistant Ms. Emmanuelle Pignard-Péguet during the preparation of this Special Issue. We are grateful to the ESPR Editorial Board and reviewers for undertaking careful review of manuscripts submitted to this Special Issue. Finally, we thank all the participants in this stimulating symposium, and in particular, the authors of the papers included in this Special Issue, which partially reflect the current international activities, results, and future directions in the field of ESB or ECs. The guest editors of this Special Issue hope these papers are a valuable contribution to the scientific literature and useful to researchers and practitioners worldwide involved in ESB and ECs.

\section{References}

Becker PR, Gunter EW, Schluter C, Shibata Y, Wise SA (2006) Environmental specimen banking. J Environ Monit 8(8):776-778

Day RD, Becker PR, Donard OFX, Pugh RS, Wise SA (2014) Environmental specimen banks as a resource for mercury and mercury isotope research in marine ecosystems. Environ Sci Proc Imp 16(1):10-27 
Iwnao H (1998) Summary report on international workshop on ultralong-term cryogenic preservation network of biological and environmental specimens. J Soc Photogr Sci Technnol Jpn 61(3):158160 , in Japanese

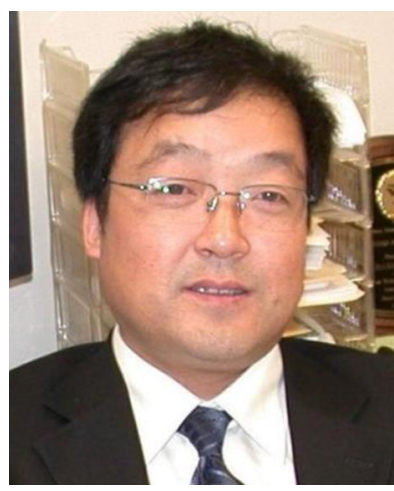

Dr. Jianfu Zhao is a professor at the College of Environmental Science and Engineering, Tongji University, China. He got his Ph.D. degree in 1990 from Tsinghua University, China. His research fields include (1) theory and technology on water pollution control, (2) behavior and effect of environmental pollutants, and (3) environmental management and policy related to sustainable development. As a principal investigator, he has finished a number of research projects supported by Ministry of Science and Technology (China), Ministry of Education (China), Science and Technology Commission of Shanghai Municipality, and other authorities. Until now, he has published over 300 original scientific articles in peer reviewed international and national journals. As the main contributor, he has got the following achievements: Thirty-six invention patents were authorized in China and one invention patent was authorized in the USA; "Coupled urban sewage treatment new technologies and application" won the second-prize award for National Technology Invention; "Key technology study and equipment development for environmental protection in small-town" won the second-prize award for Science and Technology Progress by Ministry of Education (China).

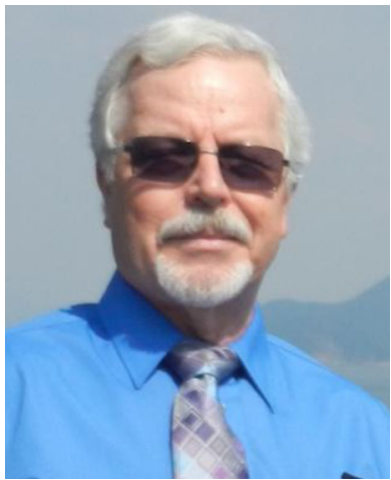

Dr. Paul R. Becker is currently the National Institute of Standards and Technology (NIST) Site Director at the Hollings Marine Laboratory, Charleston, South Carolina, USA. Dr. Becker received his Ph.D. degree in biology (1972) from Texas A\&M University and has over 35 years of experience in environmental research and research management. $\mathrm{He}$ has provided leadership in the development of environmental specimen banking programs and support facilities since 1987, and the application of these programs to contaminant monitoring and research. He has authored and coauthored numerous publications on long-term specimen banking and served on several international environmental specimen banking committees and working groups. The present environmental specimen banking operation he leads is centered at the Hollings Marine Laboratory and supports many different biological and environmental programs that are ongoing in the contiguous United States, Alaska, and the U.S. Pacific Islands Region. Under his leadership, the scope of this work is being expanded to provide a resource of samples that is applicable to research on and assessment of marine wildlife heath and as a tool for ecosystem observations. In addition to his position at NIST, Dr. Becker is adjunct professor at the College of Charleston's Grice Marine Laboratory and is an associate member of the Graduate Faculty at the Medical University of South Carolina.

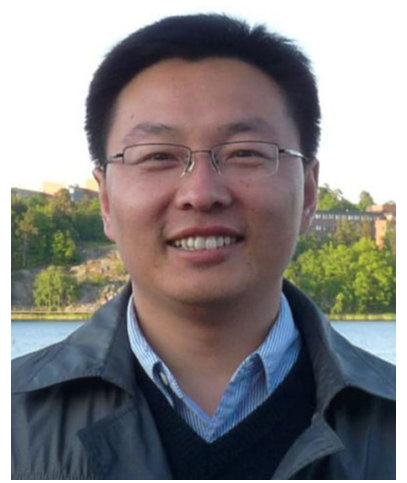

Dr. Xiang-Zhou Meng is a professor at the College of Environmental Science and Engineering, Tongji University, China. He obtained his Ph.D. degree in environmental science from the State Key Laboratory of Organic Geochemistry, Guangzhou Institute of Geochemistry, Chinese Academy of Sciences in 2007. Then, he has a 1-year scientific visit in the Southern California Coastal Water Research Project (SCCWRP) as a postdoctoral associate. In 2008, he joined Tongji University and currently direct research that focuses on the emission, fate, and risk of emerging organic contaminants during the disposal and reuse of waste products (including e-waste and sewage sludge), and the prioritization of unregulated chemicals for future monitoring, assessment, and research. Dr. Meng has published over 60 papers with $>800$ citations in peer-reviewed journals. He was awarded the President Scholarship by Chinese Academic of Sciences in 2007, the Scopus' Future Star of Researcher Award in Environmental Science (Top 10) by Science News and Elsevier's Science and Technology division in China, and the New Century Excellent Talent by Ministry of Education (China) in 2012. 